\title{
Neolignans and Norlignans from Insect Medicine Polyphaga plancyi and Their Biological Activities
}

\author{
Hong-Jie Zhu ${ }^{2} \cdot \mathrm{Te} \mathrm{Xu}^{1} \cdot$ Yong-Ming Yan ${ }^{1} \cdot$ Zheng-Chao Tu $^{3,4} \cdot$ Yong-Xian Cheng $^{1}$
}

Received: 3 July 2020 / Accepted: 23 August 2020 / Published online: 2 September 2020

(c) The Author(s) 2020

\section{Abstract}

Ten neolignans or norlignans (1-10) including eight new compounds were isolated from the whole bodies of Polyphaga plancyi Bolivar. Their structures were identified by spectroscopic data. Compounds $3,4,8$, and 9 are racemates indicated by chiral HPLC analysis. Chiral separation followed by ECD calculations allowed to clarify the absolute configurations of all the antipodes. All the new compounds were evaluated for their biological properties toward extracellular matrix in rat renal proximal tubular cells, human cancer cells (K562, A549, and Huh7), EV71, ROCK2, JAK3, DDR1, and coagulation.

\section{Graphic Abstract}

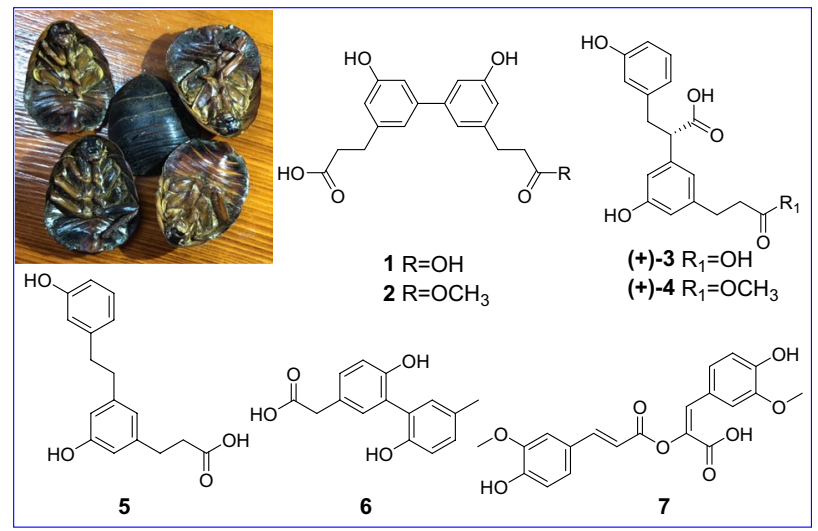

Keywords Polyphaga plancyi $\cdot$ Insect medicine $\cdot$ Lignans $\cdot$ Renal protection $\cdot$ Anticoagulant activity

In honor of Professor Jun Zhou.

Hong-Jie Zhu and Te Xu have contributed equally to this work.

Electronic supplementary material The online version of this article (https://doi.org/10.1007/s13659-020-00262-0) contains supplementary material, which is available to authorized users.

Yong-Xian Cheng

yxcheng@szu.edu.cn

1 School of Pharmaceutical Sciences, Shenzhen University Health Science Center, Shenzhen 518060, People's Republic of China

2 State Key Laboratory of Phytochemistry and Plant Resources in West China, Kunming Institute of Botany, Chinese Academy of Sciences, Kunming 650201, People's Republic of China
3 International Cooperative Laboratory of Traditional Chinese Medicine Modernization and Innovative Drug Development of Chinese Ministry of Education (MOE), College of Pharmacy, Jinan University, Guangzhou 510632, People's Republic of China

4 Drug Discovery Pipeline \& Guangdong Provincial Key Laboratory of Biocomputing, Guangzhou Institutes of Biomedicine and Health, Guangzhou 510530, People's Republic of China 


\section{Introduction}

Insects are a special group of existence on the earth. Facing the changing environment, they have strong adaptability, productivity and continuity. They seem small and insignificant, but the largest number of living beings on the planet, and their presence has created a huge molecular libraries $[1,2]$. The tenacious vitality of insects is highly likely to be related to their unique molecular mechanisms [2], which provides us a confidence to track their bioactive molecules.

In China, the insect Polyphaga plancyi Bolivar has been used for promoting blood circulation [3]. Whereas, so far there have few reports about its chemical composition [4]. Previous studies revealed the significance of structurally novel non-peptide small molecules (NPSMs) [5-11], inspiring our further interest on insect chemistry. As far as the title species was concerned, eight new compounds and two known compounds belonging to neolignans and norlignans were isolated in this study (Fig. 1). Chiral HPLC separation was used to afford optically active isomers. Subsequent absolute configuration clarification was aided by electronic circular dichroism (ECD) calculations. In addition, the biological activities of all the new compounds were assessed using multiple assays.

\section{Results and Discussion}

\subsection{Structure Elucidation of the Compounds}

Plancyin A (1) has the molecular formula $\mathrm{C}_{18} \mathrm{H}_{18} \mathrm{O}_{6}$ deduced from analysis of its HRESIMS ([M-H $]^{-}, m / z$ 329.1040, calcd 329.1031), ${ }^{13} \mathrm{C}$ NMR, and DEPT spectra, indicating 10 degrees of unsaturation. The ${ }^{1} \mathrm{H}$ NMR spectrum (Table 1 ) of $\mathbf{1}$ indicates the presence of three aromatic/olefinic protons at $\delta_{\mathrm{H}} 6.63$ (brs, H-2), 6.82 (brs, H-4), 6.90 (brs, H-6), indicating the presence of a 1,3,5-trisubstituted benzene ring. The ${ }^{13} \mathrm{C}$ NMR and DEPT spectra show 9 carbons ascribed to two methylene, three $s p^{2}$ methine, and four quaternary carbons (one carbonyl, three olefinic including one oxygenated). Based on the molecular formula, we judged that compound $\mathbf{1}$ is a completely symmetrical structure. The ${ }^{1} \mathrm{H}-{ }^{1} \mathrm{H}$ COSY spectrum (Fig. 2) shows correlations of $\mathrm{H}-7 / \mathrm{H}-8$. The HMBC correlations of H-7/C-2, C-6, C-9 ( $\left.\delta_{\mathrm{C}} 176.9\right)$,
Fig. 1 The chemical structures of compounds 1-10<smiles>[R]C(=O)CC[Te]c1cc(O)c[14c](-c2cc(O)cc([Te]CC(=O)O)c2)c1</smiles>

$1 \mathrm{R}=\mathrm{OH}$ $2 \mathrm{R}=\mathrm{OCH}_{3}$<smiles>O=C(O)Cc1ccc(O)c(-c2cc(I)ccc2O)c1</smiles>

6

$(+)-9$<smiles>OC[C@H]1OC[C](c2ccc(O)c(O)c2)c2cc(O)c(O)cc21</smiles><smiles>[R]C(=O)CCc1cc(O)cc([C@H](Cc2cccc(O)c2)C(=O)O)c1</smiles>

(+)-3 $\mathrm{R}_{1}=\mathrm{OH}$ $(+)-4 \mathrm{R}_{1}=\mathrm{OCH}_{3}$<smiles>O=C(O)CCc1cc(O)cc(CCc2cccc(O)c2)c1</smiles>

5<smiles>COc1cc(/C=C/C(=O)OC(=[Te]c2ccc(O)c(OC)c2)C(=O)O)ccc1O</smiles>

7

$(+)-8$<smiles>COc1cc(CCC(=O)O)cc(-c2cc(CCC(=O)O)cc(OC)c2O)c1O</smiles> 
Table $1{ }^{1} \mathrm{H}(600 \mathrm{MHz})$ and ${ }^{13} \mathrm{C}$ NMR (150 MHz) data of 1-3 $(\delta$ in ppm, $J$ in $\mathrm{Hz}$, in methanol- $\left.d_{4}\right)$
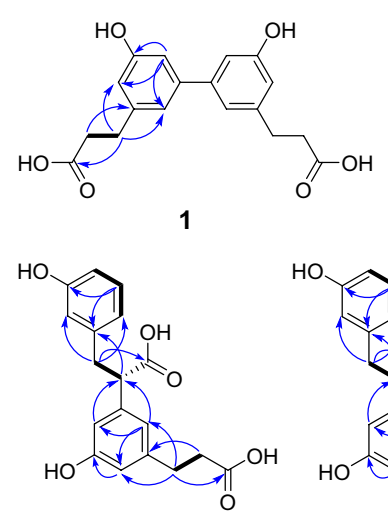

3

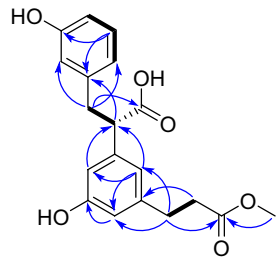

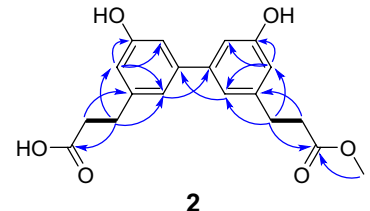

2

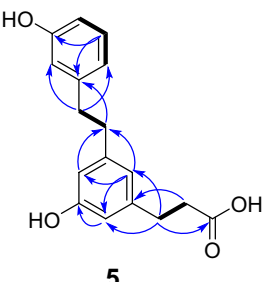

Fig. $2{ }^{1} \mathrm{H}-{ }^{1} \mathrm{H}$ COSY (black bond) and key HMBC (blue arrow) correlations of 1-5

H-8/C-1, and H-4/C-2, C-3 ( $\left.\delta_{\mathrm{C}} 158.8\right)$, C-6 allow to establish half the structure fragment of $\mathbf{1}$. Taken together, the structure of $\mathbf{1}$ was established as shown.

Plancyin B (2) has a molecular formula of $\mathrm{C}_{19} \mathrm{H}_{20} \mathrm{O}_{6}$ derived from its HREIMS $\left(\mathrm{m} / z, 343.1193[\mathrm{M}-\mathrm{H}]^{-}\right.$, calcd for 343.1187), ${ }^{13} \mathrm{C}$ NMR, and DEPT spectra, having 10 degrees of unsaturation. The ${ }^{1} \mathrm{H}$ and ${ }^{13} \mathrm{C}$ NMR data of 2 resemble those of $\mathbf{1}$, differing in that the additional existence of a methyl in 2. The HMBC correlation of $\mathrm{H}-10^{\prime}\left(\delta_{\mathrm{H}} 3.65\right.$, s)/C$9^{\prime}\left(\delta_{\mathrm{C}} 175.2\right)$ indicates the connection position of the methyl group as shown. With these in hand, the structure of $\mathbf{2}$ was readily determined.

Plancyin C (3) possesses a molecular formula $\mathrm{C}_{18} \mathrm{H}_{18} \mathrm{O}_{6}$ (10 degrees of unsaturation) deduced from its negative HRESIMS at $m / z 329.1036[\mathrm{M}-\mathrm{H}]^{-}$(calcd for 329.1031) and NMR data. The ${ }^{1} \mathrm{H}$ NMR spectrum (Table 1) indicates the presence of seven aromatic/olefinic protons. The ${ }^{13} \mathrm{C}$ NMR and DEPT spectra display 18 carbons, of which twelve are olefinic carbons belonging to two phenyl groups. Besides, the residual signals include three methylene, one $s p^{3}$ methine, and two quaternary carbons. The ${ }^{1} \mathrm{H}-{ }^{1} \mathrm{H}$ COSY spectrum (Fig. 2) shows correlations of H-4/H-5/H-6, H-7/ $\mathrm{H}-8$ and $\mathrm{H}-7^{\prime} / \mathrm{H}-8^{\prime}$. The HMBC correlations of $\mathrm{H}-7 / \mathrm{C}-2$, C-6, C-9 $\left(\delta_{\mathrm{C}} 177.7\right), \mathrm{H}-8 / \mathrm{C}-1\left(\delta_{\mathrm{C}} 142.5\right)$, in consideration of the chemical shift of $\mathrm{C}-1$, indicate the presence of phenylpropanoid (part A). The HMBC correlations of $\mathrm{H}-7^{\prime} / \mathrm{C}-2^{\prime}$, C-6 ${ }^{\prime}, \mathrm{C}-9^{\prime}\left(\delta_{\mathrm{C}} 177.4\right)$ and $\mathrm{H}-8^{\prime} / \mathrm{C}-1^{\prime}\left(\delta_{\mathrm{C}} 143.9\right)$ allow to establish the structure fragment of another phenylpropanoid (part B). In addition, the chemical shift of $\mathrm{C}^{-5} 5^{\prime}$ and the HMBC correlations of $\mathrm{H}-4^{\prime}, \mathrm{H}-6^{\prime} / \mathrm{C}-8\left(\delta_{\mathrm{C}} 55.3\right)$ indicate that parts $\mathrm{A}$ and $\mathrm{B}$ in $\mathbf{3}$ are linked via $\mathrm{C}-8-\mathrm{C}-5^{\prime}$. Taken together, the data enable assignment of the planar structure of 3 . The lack of an optical rotation indicates that $\mathbf{3}$ is racemic. Separation by using chiral HPLC yielded two enantiomers, whose absolute configurations at stereogenic centers were assigned using computational methods. The ECD spectrum of $(8 S)-3$ is correlated well with the experimental spectrum of (+)-3, 


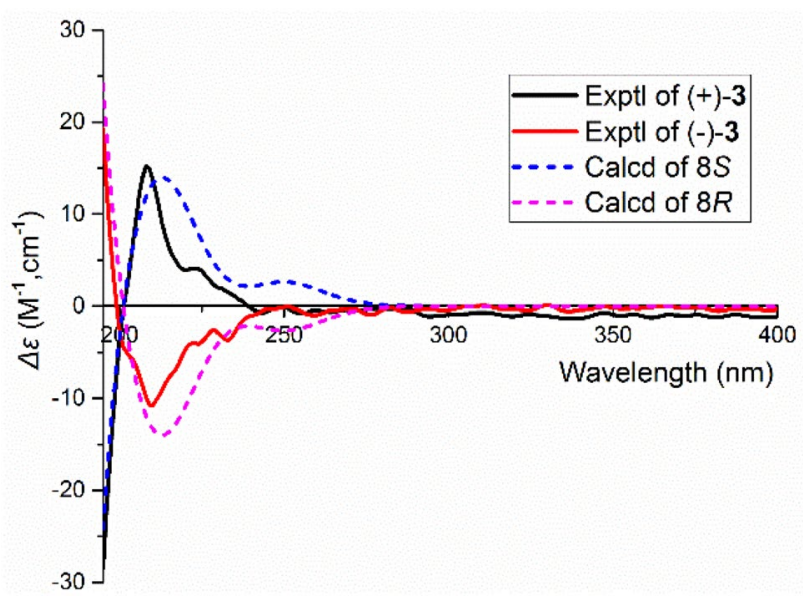

Fig. 3 Comparison of calculated ECD spectra for $(8 S)-\mathbf{3}$ and $(8 R)$ 3 with the experimental spectra of (+)-3 and (-)-3 in $\mathrm{MeOH}$. $\sigma=0.3 \mathrm{eV}$; shift $=-10 \mathrm{~nm}$

leading to the unambiguous assignment of the absolute configurations at the stereogenic centers in (+)-3 as 8S (Fig. 3).

Plancyin D (4) has the molecular formula $\mathrm{C}_{19} \mathrm{H}_{20} \mathrm{O}_{6}(10$ degrees of unsaturation), based on analysis of its HREIMS, ${ }^{13} \mathrm{C}$ NMR, and DEPT spectra. The ${ }^{1} \mathrm{H}$ and ${ }^{13} \mathrm{C}$ NMR data of 4 resemble those of $\mathbf{3}$, differing in that the additional existence of a methyl in 4. The HMBC correlation of $\mathrm{H}-10^{\prime}\left(\delta_{\mathrm{H}}\right.$ $3.63, \mathrm{~s}) / \mathrm{C}-9^{\prime}\left(\delta_{\mathrm{C}} 175.2\right)$ indicates the connection position of the methyl group as shown. Thus, the planar structure of $\mathbf{4}$ was determined. For the structure like $\mathbf{3}$, it is challenging to clarify the stereochemistry at C-8. Separation of $\mathbf{4}$ by chiral HPLC afforded (+)-4 and (-)-4, whose absolute configurations were further determined by ECD calculations and comparison (Supplementary material) with the data of $\mathbf{3}$, allowing (+)-4 to be $8 S$.

Plancyin E (5) has the molecular formula $\mathrm{C}_{17} \mathrm{H}_{18} \mathrm{O}_{4}(9$ degrees of unsaturation), based on analysis of its HREIMS and NMR data. Inspection of these NMR data disclosed that the structure of $\mathbf{5}$ extremely resemble that of $\mathbf{3}$, differing in that a carboxyl group of $\mathrm{C}-8$ is absent gaining support from the HMBC correlations of $\mathrm{H}-8 / \mathrm{C}-1, \mathrm{C}-4^{\prime}, \mathrm{C}-6^{\prime}$ and the chemical shift of C-8 $\left(\delta_{\mathrm{C}} 39.0\right)$. Therefore, the structure of 5 was constructed.

Plancyin $\mathrm{F}(6)$ possesses a molecular formula $\mathrm{C}_{15} \mathrm{H}_{14} \mathrm{O}_{4}$ deduced from its negative HRESIMS and NMR data, indicating 9 degrees of unsaturation. The ${ }^{1} \mathrm{H}$ NMR spectrum of 6 shows two ABX systems indicated by the signals at $\delta_{\mathrm{H}} 7.15$ (d, $J=1.8 \mathrm{~Hz}, \mathrm{H}-2)$, and 6.86 (d, $J=8.1 \mathrm{~Hz}, \mathrm{H}-5), 7.13$ (dd, $J=8.1,1.8 \mathrm{~Hz}, \mathrm{H}-6)$ and $\delta_{\mathrm{H}} 7.05\left(\mathrm{~d}, J=1.9 \mathrm{~Hz}, \mathrm{H}-2^{\prime}\right), 6.80$ $\left(\mathrm{d}, J=8.1 \mathrm{~Hz}, \mathrm{H}-5^{\prime}\right)$, and $7.01\left(\mathrm{dd}, J=8.1,1.9 \mathrm{~Hz}, \mathrm{H}-6^{\prime}\right)$, suggesting the presence of two 1,2,4-trisubstituted benzene rings. In addition, there exists a signal at $\delta_{\mathrm{H}} 3.53(\mathrm{~s}, 2 \mathrm{H}$, $\mathrm{H}-7)$ and a methyl signal at $\delta_{\mathrm{H}} 2.28\left(\mathrm{~s}, 3 \mathrm{H}, \mathrm{H}-7^{\prime}\right)$. The ${ }^{13} \mathrm{C}$ NMR and DEPT spectra display 15 carbons ascribed to one methyl, one methylene, six $s p^{2}$ methine, seven quaternary carbons (one carbonyl, six $s p^{2}$ including two oxygenated). The ${ }^{1} \mathrm{H}-{ }^{1} \mathrm{H}$ COSY spectrum (Fig. 4) gives cross peaks of H-5/H-6 and H-5'/H-6', in conjunction with the HMBC correlations of $\mathrm{H}-7 / \mathrm{C}-2, \mathrm{C}-6, \mathrm{C}-8\left(\delta_{\mathrm{C}} 177.3\right)$, and the chemical shift of C-4 $\left(\delta_{\mathrm{C}} 154.0\right)$, revealing the west part of $\mathbf{6}$. The HMBC correlations of $\mathrm{H}-7^{\prime} / \mathrm{C}-1^{\prime}, \mathrm{C}-2^{\prime}, \mathrm{C}-6^{\prime}$ and $\mathrm{H}-6^{\prime} / \mathrm{C}-4^{\prime}$ $\left(\delta_{\mathrm{C}} 152.7\right)$ allow to establish the structure fragment of the east part. Two parts are connected via $\mathrm{C}-3-\mathrm{C}-3^{\prime}$ aided by the HMBC correlations of $\mathrm{H}-2 / \mathrm{C}-3^{\prime}$ and $\mathrm{H}-2^{\prime} / \mathrm{C}-3$. The structure of 6 was therefore identified.

Plancyin G (7) has the molecular formula $\mathrm{C}_{20} \mathrm{H}_{18} \mathrm{O}_{8}(12$ degrees of unsaturation) deduced from its HRESIMS and NMR data. The ${ }^{1} \mathrm{H}$ NMR spectrum of 7 shows the presence of two doublets at $\delta_{\mathrm{H}} 7.59$ and $\delta_{\mathrm{H}} 6.37$ both with $J$ value of $15.9 \mathrm{~Hz}$, indicating the trans relationship of $\mathrm{H}-7$ and $\mathrm{H}-8$, two ABX systems characteristic of signals at $\delta_{\mathrm{H}} 7.31(\mathrm{~d}$, $J=1.7 \mathrm{~Hz}, \mathrm{H}-2), 6.78(\mathrm{~d}, J=8.3 \mathrm{~Hz}, \mathrm{H}-5)$, and 7.06 (dd, $J=8.3,1.7 \mathrm{~Hz}, \mathrm{H}-6)$ and $\delta_{\mathrm{H}} 7.43\left(\mathrm{~d}, J=1.7 \mathrm{~Hz}, \mathrm{H}-2^{\prime}\right), 6.74$ $\left(\mathrm{d}, J=8.3 \mathrm{~Hz}, \mathrm{H}-5^{\prime}\right)$, and $7.08\left(\mathrm{dd}, J=8.3,1.7 \mathrm{~Hz}, \mathrm{H}-6^{\prime}\right)$, and two methyl signals respectively at $\delta_{\mathrm{H}} 3.96(\mathrm{~s}, \mathrm{H}-10)$ and $\delta_{\mathrm{H}} 3.69\left(\mathrm{~s}, \mathrm{H}-10^{\prime}\right)$. The ${ }^{13} \mathrm{C}$ NMR and DEPT spectra display 20 carbons ascribed to two methyl, nine $s p^{2}$ methine, nine quaternary carbons (two carbonyl, seven $s p^{2}$ including five oxygenated). The architecture of 7 was constructed mainly based on the HMBC spectrum (Fig. 4). In the HMBC spectrum, the correlations of $\mathrm{H}-7 / \mathrm{C}-2, \mathrm{C}-6, \mathrm{C}-9\left(\delta_{\mathrm{C}} 170.8\right)$, H-7'/C-2', C-6', C-9' $\left(\delta_{\mathrm{C}} 167.7\right)$ indicate the presence of two phenylpropanoid parts, the correlations of H-5, H-10/C-3 $\left(\delta_{\mathrm{C}}\right.$ $150.5), \mathrm{H}-5^{\prime}, \mathrm{H}-10^{\prime} / \mathrm{C}-3^{\prime}\left(\delta_{\mathrm{C}} 148.9\right)$ and ROESY correlations H-2/H-10, H-2'/H-10' indicate the position of methoxyl, respectively. Further, a pivotal ROESY correlation of $\mathrm{H}-8 / \mathrm{H}-$ $7^{\prime}$ in consideration of the chemical shift of C-8' $\left(\delta_{\mathrm{C}} 139.9\right)$ suggests the position of ester oxygen and the presence of $E$-configurated olefinic protons ( $\mathrm{H}-7^{\prime}$ and $\left.\mathrm{H}-8^{\prime}\right)$, in accordance with the requirement of degrees of unsaturation. Taken together, these data enable assignment of the structure of 7 .
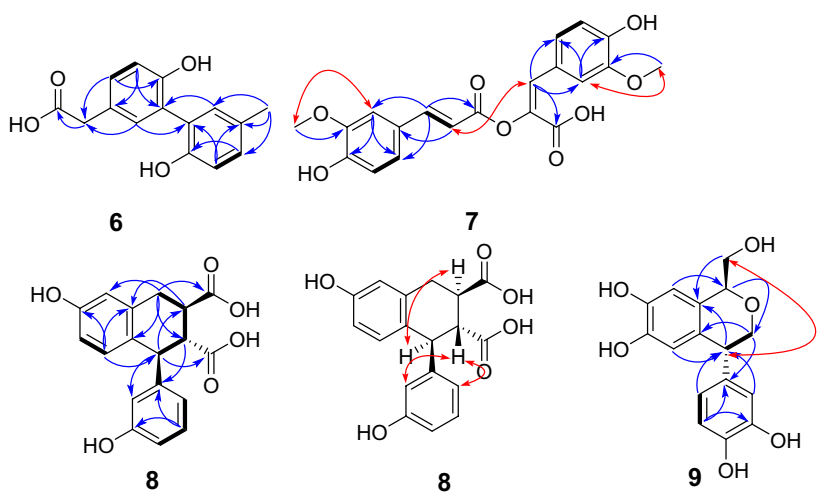

Fig. $4{ }^{1} \mathrm{H}-{ }^{1} \mathrm{H}$ COSY (black bond), Key HMBC (blue arrow), and ROESY (red arrow) correlations of 6-9 
Plancyin $\mathrm{H}(\mathbf{8})$ possesses a molecular formula $\mathrm{C}_{18} \mathrm{H}_{16} \mathrm{O}_{6}$ (11 degrees of unsaturation) deduced from its HRESIMS and NMR data. The ${ }^{1} \mathrm{H}$ NMR spectrum indicates the presence of seven aromatic/olefinic protons. The ${ }^{13} \mathrm{C}$ NMR and DEPT spectra display 18 carbons, of which twelve are olefinic carbons belonging to two phenyl groups. Besides, the residual signals include one methylene, three $s p^{3}$ methine, and two quaternary carbons (carbonyl). The HMBC correlations (Fig. 4) of H-7/C-2, C-6, C-9 $\left(\delta_{\mathrm{C}} 178.3\right), \mathrm{H}-8 / \mathrm{C}-1$, and the ${ }^{1} \mathrm{H}-{ }^{1} \mathrm{H}$ COSY correlation of $\mathrm{H}-7 / \mathrm{H}-8$ indicate the substructure of C-1-C-7-C-8-C-9 (part A). The structure fragment C-1'-C-7'-C-8'-C-9' (part B) was established the HMBC correlations of $\mathrm{H}-7^{\prime} / \mathrm{C}-2^{\prime}, \mathrm{C}-6^{\prime}, \mathrm{C}-9^{\prime}\left(\delta_{\mathrm{C}} 178.4\right), \mathrm{H}-8^{\prime} / \mathrm{C}-1^{\prime}$, and the ${ }^{1} \mathrm{H}-{ }^{1} \mathrm{H}$ COSY correlation of $\mathrm{H}-7^{\prime} / \mathrm{H}-8^{\prime}$. Further, the ${ }^{1} \mathrm{H}-{ }^{1} \mathrm{H}$ COSY correlation of $\mathrm{H}-8 / \mathrm{H}-8^{\prime}$ and the HMBC correlations of $\mathrm{H}-5 / \mathrm{C}-7^{\prime}, \mathrm{H}-7 / \mathrm{C}-8^{\prime}$, and $\mathrm{H}-7^{\prime} / \mathrm{C}-8$ suggests two parts are connected via $\mathrm{C}-6-\mathrm{C}-7^{\prime}$ and $\mathrm{C}-8-\mathrm{C}-8^{\prime}$. The ${ }^{1} \mathrm{H}-{ }^{1} \mathrm{H}$ COSY correlations of H-4/H-5, H-5'/H-4', H-6', and HMBC correlations of $\mathrm{H}-5 / \mathrm{C}-1, \mathrm{C}-3\left(\delta_{\mathrm{C}} 156.6\right)$ and $\mathrm{H}-5^{\prime} / \mathrm{C}-1^{\prime}, \mathrm{C}-3^{\prime}$ $\left(\delta_{\mathrm{C}} 158.4\right)$ indicate the replacement of benzene ring. Taken together, the planar structure of $\mathbf{8}$ was established as shown. There are three chiral centers in $\mathbf{8}$, the ROESY correlations (Fig. 4) of H-8/H-7' and H-8'/H-2', H-6' evidently imply the relative configuration of $\mathbf{8}$. Compound $\mathbf{8}$ is racemic, chiral HPLC separation afforded (+)-8 and (-)-8, whose absolute configurations was further determined as $8 R, 7^{\prime} S, 8^{\prime} R$ for (+)8 and $8 S, 7^{\prime} R, 8^{\prime} S$ for (-)-8 by ECD comparison (Fig. 5).

Compound 9 was determined to have the molecular formula $\mathrm{C}_{16} \mathrm{H}_{16} \mathrm{O}_{6}$ (9 degrees of unsaturation) on the basis of HRESIMS and NMR data. The ${ }^{1} \mathrm{H}$ NMR spectrum shows an $\mathrm{ABX}$ system with signals resonated at $\delta_{\mathrm{H}} 6.53$ $\left(\mathrm{d}, J=1.6 \mathrm{~Hz}, \mathrm{H}-2^{\prime}\right), 6.69\left(\mathrm{~d}, J=8.0 \mathrm{~Hz}, \mathrm{H}-5^{\prime}\right)$, and 6.50 (dd, $\left.J=8.0,1.6 \mathrm{~Hz}, \mathrm{H}-6^{\prime}\right)$. Two aromatic protons at $\delta_{\mathrm{H}}$ $6.58(\mathrm{~s}, \mathrm{H}-2)$ and $\delta_{\mathrm{H}} 6.31(\mathrm{~s}, \mathrm{H}-5)$ suggest the presence of

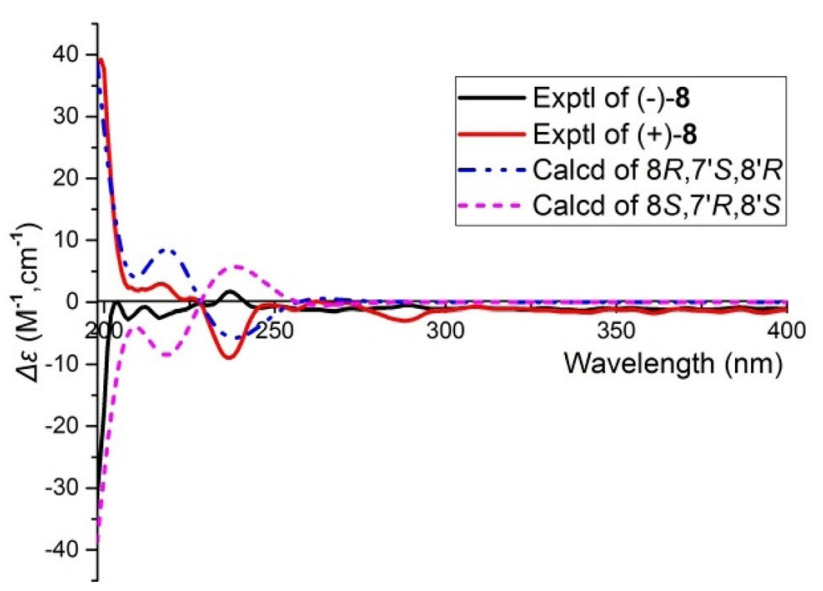

Fig. 5 Comparison of calculated ECD spectra for $\left(8 R, 7^{\prime} S, 8^{\prime} R\right)-\mathbf{8}$ and $\left(8^{\prime} S, 7^{\prime} R, 8^{\prime} S\right)-\mathbf{8}$ with the experimental spectra of (+)-8 and (-)-8 in MeOH. $\sigma=0.3 \mathrm{eV}$; shift $=-7 \mathrm{~nm}$ a 1,2,4,5-tetrasubstituted benzene ring. The ${ }^{13} \mathrm{C}$ NMR and DEPT spectra indicate 16 carbons ascribed to two oxygenated methylene, seven methine ( $5 s p^{2}$ and $\left.2 s p^{3}\right)$, and seven quaternary carbons ( 4 oxygenated). The ${ }^{1} \mathrm{H}-{ }^{1} \mathrm{H}$ COSY spectrum shows correlations of $\mathrm{H}-5^{\prime} / \mathrm{H}-6^{\prime} ; \mathrm{H}-7 / \mathrm{H}-8$, and $\mathrm{H}-7^{\prime} / 8^{\prime}$. The HMBC correlations of $\mathrm{H}-7^{\prime} / \mathrm{C}-1, \mathrm{C}-1^{\prime}, \mathrm{C}-2^{\prime}, \mathrm{C}-6$ and $\mathrm{C}-6$ ' indicate that the two phenyl groups are connected via C-7'. The HMBC correlations of H-8/C-1, H-2/C-7, H-7/C$8^{\prime}$, and $\mathrm{H}-8^{\prime} / \mathrm{C}-1^{\prime}$, C-6 suggest the structural motif of an isochroman. Taken together, the planar structure of 9 was determined as shown. There are two chiral centers in $\mathbf{9}$, the ROESY spectrum (Fig. 4) of $\mathbf{9}$ displays the correlation of $\mathrm{H}-7^{\prime} / \mathrm{H}-8$. We found that the NMR data of compound 9 are exactly same as those of periplanol A [20]. However, the absolute configuration of periplanol A has not been determined yet. To clarify the absolute configuration of $\mathbf{9}$, chiral HPLC separation was first conducted due to it is racemic. The absolute configuration of each enantiomer of racemic 9 was assigned by using ECD calculations. The ECD spectrum (Fig. 6) of $\left(7 R, 7^{\prime} S\right)-9$ agrees well with the experimental one of (-)-9, leading to the unambiguous assignment of the absolute configurations at the stereogenic centers in (-)-9 as $7 R, 7^{\prime} S$ and (+)-9 as $7 S, 7^{\prime} R$ (Tables 2 and 3).

The known compound (10) was identified as 5-5' dehydrodi-3-(4-hydroxy-3-methoxyphenyl) propionic acid by comparing its NMR data with those in the literature [21].

Proteins or peptides are commonly considered to be the active substances in the insects. However, the chemical profiling and biological role of nonpeptidal small molecules in the insects remains largely unknown. In this study, ten lignan derivatives were characterized. It is evident that compounds $\mathbf{5 , 6}$, and $\mathbf{9}$ are diverse norlignans and there exist four types of connection pattern for the ten lignans, adding new facets for the insect derived natural products.

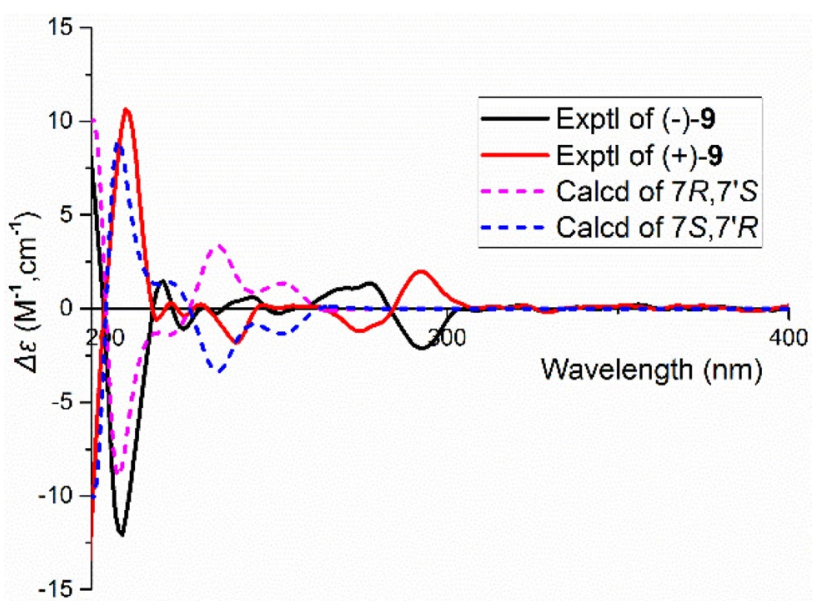

Fig. 6 Comparison of calculated ECD spectra for $\left(7 S, 7^{\prime} R\right)-9$ and $\left(7 R, 7^{\prime} S\right)-9$ with the experimental spectra of (+)-9 and (-)-9 in MeOH. $\sigma=0.3 \mathrm{eV}$; shift $=-3 \mathrm{~nm}$ 
Table $2{ }^{1} \mathrm{H}(600 \mathrm{MHz})$ and ${ }^{13} \mathrm{C}$ NMR $(150 \mathrm{MHz})$ data of 4-6 $(\delta$ in ppm, $J$ in $\mathrm{Hz}$, in methanol- $d_{4}$ )

\begin{tabular}{|c|c|c|c|c|c|c|}
\hline \multirow[t]{2}{*}{ No. } & \multicolumn{2}{|l|}{4} & \multicolumn{2}{|l|}{5} & \multicolumn{2}{|l|}{6} \\
\hline & $\delta_{\mathrm{H}}$ & $\delta_{\mathrm{C}}$ & $\delta_{\mathrm{H}}$ & $\delta_{\mathrm{C}}$ & $\delta_{\mathrm{H}}$ & $\delta_{\mathrm{C}}$ \\
\hline 1 & & 142.7 & & 144.7 & & 128.4 \\
\hline 2 & 6.58 , brs & 116.9 & 6.60, brs & 116.3 & $7.15, \mathrm{~d}, 1.8$ & 133.6 \\
\hline 3 & & 158.2 & & 158.4 & & 127.7 \\
\hline 4 & $6.55, \mathrm{dd}, 8.1,1.9$ & 114.0 & $6.58, \mathrm{dd}, 8.1,1.9$ & 113.7 & & 154.0 \\
\hline 5 & 7.00, t-like & 130.1 & 7.04, t-like & 130.2 & $6.86, \mathrm{~d}, 8.1$ & 117.4 \\
\hline 6 & 6.60 , overlap & 121.3 & 6.63 , overlap & 120.8 & $7.13, \mathrm{dd}, 8.1,1.8$ & 130.5 \\
\hline 7 & $\begin{array}{l}3.23, \mathrm{dd}, 13.6,8.5 \\
2.84, \mathrm{dd}, 13.6,6.7\end{array}$ & 40.9 & 2.76 , overlap & 39.0 & $3.53, \mathrm{~s}$ & 41.9 \\
\hline 8 & 3.66 , overlap & 55.8 & 2.76 , overlap & 39.0 & & 177.3 \\
\hline 9 & & 178.3 & & 177.4 & & \\
\hline $1^{\prime}$ & & 143.4 & & 143.6 & & 130.6 \\
\hline $2^{\prime}$ & 6.50 , brs & 114.8 & 6.47 , brs & 113.7 & $7.05, \mathrm{~d}, 1.9$ & 133.0 \\
\hline $3^{\prime}$ & & 158.6 & & 158.3 & & 127.3 \\
\hline $4^{\prime}$ & 6.62 , brs & 113.9 & 6.45, brs & 114.2 & & 152.7 \\
\hline $5^{\prime}$ & & 142.9 & & 144.7 & $6.80, \mathrm{~d}, 8.1$ & 117.3 \\
\hline $6^{\prime}$ & 6.63 , brs & 120.5 & 6.51, brs & 120.9 & $7.01, \mathrm{dd}, 8.1,1.9$ & 130.2 \\
\hline $7^{\prime}$ & $2.79, \mathrm{t}, 7.6$ & 31.9 & $2.78, \mathrm{t}, 7.7$ & 32.2 & $2.28, \mathrm{~s}$ & 20.6 \\
\hline $8^{\prime}$ & $2.56, \mathrm{t}, 7.6$ & 36.6 & $2.51, \mathrm{t}, 7.7$ & 37.2 & & \\
\hline $9^{\prime}$ & & 175.2 & & 177.4 & & \\
\hline $10^{\prime}$ & $3.63, \mathrm{~s}$ & 52.1 & & & & \\
\hline
\end{tabular}

Table $3{ }^{1} \mathrm{H}(600 \mathrm{MHz})$ and ${ }^{13} \mathrm{C}$ NMR $(150 \mathrm{MHz})$ data of 7-9 $(\delta$ in ppm, $J$ in $\mathrm{Hz})$

\begin{tabular}{|c|c|c|c|c|c|c|c|}
\hline \multirow[t]{2}{*}{ No. } & \multicolumn{2}{|l|}{7} & \multicolumn{3}{|l|}{8} & \multicolumn{2}{|l|}{9} \\
\hline & $\delta_{\mathrm{H}}{ }^{\mathrm{a}}$ & $\delta_{\mathrm{C}}{ }^{\mathrm{a}}$ & $\delta_{\mathrm{H}}^{\mathrm{a}}$ & $\delta_{\mathrm{H}}^{\mathrm{b}}$ & $\delta_{\mathrm{C}}{ }^{\mathrm{a}}$ & $\overline{\delta_{\mathrm{H}}{ }^{\mathrm{a}}}$ & $\delta_{\mathrm{C}}{ }^{\mathrm{a}}$ \\
\hline 1 & & 130.4 & & & 136.9 & & 127.0 \\
\hline 2 & $7.31, \mathrm{~d}, 1.7$ & 112.6 & 6.57 , overlap & 7.03 , overlap & 115.1 & $6.58, \mathrm{~s}$ & 111.9 \\
\hline 3 & & 150.5 & & & 156.6 & & 145.0 \\
\hline 4 & & 149.4 & $6.47, \mathrm{dd}, 8.5,2.1$ & 6.91, brd, 7.3 & 114.9 & & 145.2 \\
\hline 5 & $6.78, \mathrm{~d}, 8.3$ & 114.7 & $6.52, \mathrm{~d}, 8.5$ & $6.96, \mathrm{~d}, 7.8$ & 131.5 & $6.31, \mathrm{~s}$ & 116.8 \\
\hline 6 & $7.06, \mathrm{dd}, 8.3,1.7$ & 123.2 & & & 130.5 & & 131.2 \\
\hline 7 & $7.59, \mathrm{~d}, 15.9$ & 146.0 & 3.07, overlap & 3.42 , overlap & 34.0 & $4.76, \mathrm{dd}, 5.2,2.5$ & 78.4 \\
\hline 8 & $6.37, d, 15.9$ & 117.8 & 3.03 , overlap & 3.42 , overlap & 45.7 & 3.86 , overlap; $3.74, \mathrm{dd}, 11.8,5.2$ & 66.3 \\
\hline 9 & & 170.8 & & & 178.3 & & \\
\hline 10 & $3.96, \mathrm{~s}$ & 56.7 & & & & & \\
\hline $1^{\prime}$ & & 125.9 & & & 147.0 & & 135.6 \\
\hline $2^{\prime}$ & $7.43, \mathrm{~d}, 1.7$ & 113.8 & 6.57 , overlap & 7.03 , overlap & 117.1 & $6.53, \mathrm{~d}, 1.6$ & 117.0 \\
\hline $3^{\prime}$ & & 148.9 & & & 158.4 & & 146.2 \\
\hline $4^{\prime}$ & & 149.6 & $6.65, \mathrm{dd}, 8.1,1.8$ & 7.08, brd, 7.5 & 114.7 & & 145.1 \\
\hline $5^{\prime}$ & $6.74, \mathrm{~d}, 8.3$ & 116.2 & 7.09, t-like & 7.27, t-like & 130.4 & $6.69, \mathrm{~d}, 8.0$ & 116.2 \\
\hline $6^{\prime}$ & $7.08, \mathrm{dd}, 8.3,1.7$ & 126.3 & 6.62, brd, 7.6 & 7.34 , brs & 121.7 & $6.50, \mathrm{dd}, 8.0,1.6$ & 121.5 \\
\hline $7^{\prime}$ & $7.35, \mathrm{~s}$ & 128.2 & $4.06, d, 10.3$ & $4.73, d, 10.2$ & 50.2 & 3.87 , overlap & 45.0 \\
\hline $8^{\prime}$ & & 139.9 & 2.97 , overlap & 3.80, t-like & 53.6 & $4.10, \mathrm{dd}, 11.0,5.1 ; 3.64, \mathrm{dd}, 11.0,8.9$ & 71.1 \\
\hline $9^{\prime}$ & & 167.7 & & & 178.4 & & \\
\hline $10^{\prime}$ & $3.69, \mathrm{~s}$ & 56.0 & & & & & \\
\hline
\end{tabular}

${ }^{\mathrm{a}}$ In methanol- $d_{4}$

${ }^{\mathrm{b}}$ In pyridine- $d_{5}$ 


\subsection{Biological Evaluation}

To explore the mechanism underlying the antifibrotic effect of the compounds, we first examined whether the compounds affected TGF- $\beta 1$-induced activation of the marker genes in NRK-52e cells ( $40 \mu \mathrm{M}$, data not shown). As presented in Fig. 7, compound 1 reduces three marker genes, especially for fibronectin and $\alpha$-SMA in TGF- $\beta 1$-induced NRK-52e cells (Fig. 7a). Compound 7 significantly inhibits three marker genes (Fig. 7b). Besides, Western bolt assay shows that compounds $\mathbf{1}$ and $\mathbf{7}$ decrease the protein expression with a dose-dependent manner in TGF- $\beta 1$ induced NRK-52e cells (Fig. 8a, b). Next, we assessed the expression of Smad2/3 phosphorylation in NRK-52e cells. As presented in Fig. 9, compound 1 inhibits Smad3 phosphorylation, but does not affect TGF- $\beta 1$-induced Smad2 phosphorylation (Fig. 9a). Compound 7 decreases both Smad3 and Smad2 phosphorylation level, and the effect for Smad2 appears to be more potent than Smad3 at $40 \mu \mathrm{M}$
(Fig. 9b). Although more investigation are needed, our current study provides evidence that compounds $\mathbf{1}$ and $\mathbf{7}$ can play potential roles in the therapy of renal fibrosis by the disruption of Smad activation.

In addition, all the new compounds were evaluated for their inhibitory activities against human cancer cells (K562, A549, and Huh7), EV71, ROCK2, JAK3, DDR1, and coagulation. Compounds (+)-3 and (-)-3 show cytotoxicity against K562, A549, and Huh-7 cell lines with $\mathrm{IC}_{50}$ values ranging from 16.6 to $67.7 \mu \mathrm{M}$ (Table 4$)$. In contrast, compounds (+)-3 and (-)-3 also exhibit inhibitory activity against EV71 with $\mathrm{IC}_{50}$ values of $23.2 \mu \mathrm{M}$ and $27.1 \mu \mathrm{M}$, respectively. It was found that compound 6 exhibits potent inhibitory activities toward these kinases with $\mathrm{IC}_{50}$ values of $9.17 \mu \mathrm{M}$ for JAK3 and $27.1 \mu \mathrm{M}$ for ROCK2. Compounds (+)-9 and (-)-9 exhibit inhibitory activities against JAK3 and DDR1 kinases (Table 5). In addition, partial compounds exhibit negligible inhibitory effect on coagulant (Tables 6, 7 and 8).

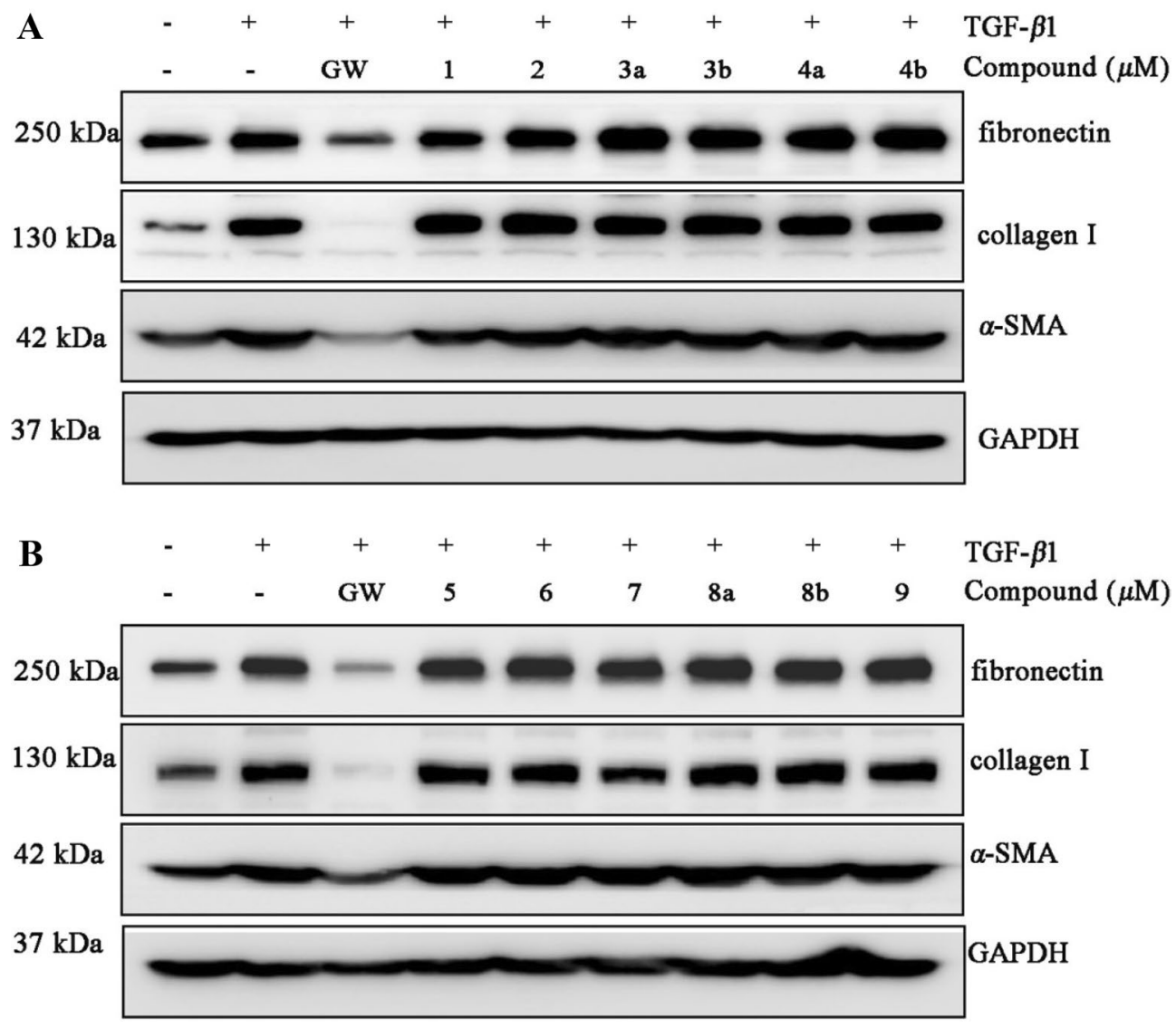

Fig. 7 Western blot analysis showing that $\mathbf{1}$ and $\mathbf{7}$ protect against TGF- $\beta 1$-mediated renal fibrosis. NRK-52e cells were incubated with TGF- $\beta 1(10 \mathrm{ng} / \mathrm{mL})$ for $48 \mathrm{~h}$ in the absence or presence of the compounds $(40 \mu \mathrm{M})$. Cell lysates were immunoblotted with antibod- ies against fibronectin, collagen I, $\alpha$-SMA, and GAPDH. GAPDH and GW were used as a normalizing control and a positive control, respectively. GW: GW788388 (Medchemexpree, HY-10326) 


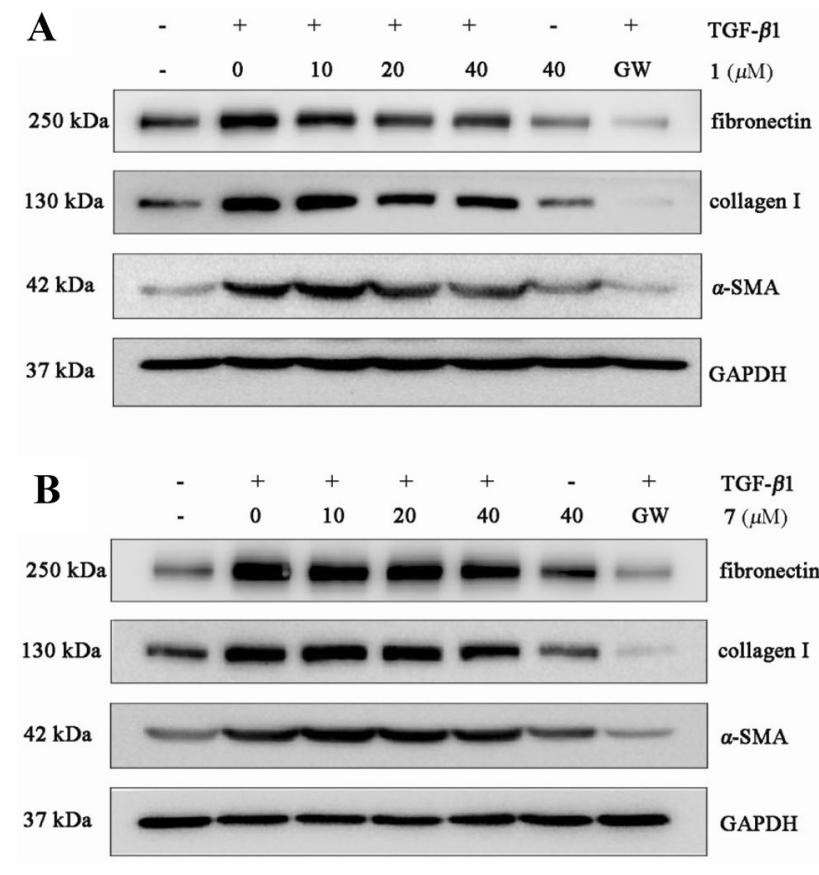

Fig. 8 Western blot analysis showing that 1 and $\mathbf{7}$ block TGF- $\beta 1$ mediated renal fibrosis. NRK-52e cells were preincubated with different concentrations of the compounds for $48 \mathrm{~h}$ before TGF- $\beta 1$ (10 ng/ $\mathrm{mL}$ ) treatment. Cell lysates were immunoblotted with antibodies against fibronectin, collagen I, $\alpha$-SMA, and GAPDH

\section{Experimental Section}

\subsection{General Experimental Procedures}

Optical rotations were recorded on a Horiba SEPA-300 polarimeter. UV spectra were measured on a Shimadzu UV-2401PC spectrometer. CD spectra were determined on a Chirascan instrument. NMR spectra were recorded on a Bruker AV-600 MHz spectrometer, with TMS as an internal standard. ESIMS and HRESIMS were collected on an Agilent 1290 UPLC/6540 Q-TOF spectrometer. C-18 silica gel (40-60 $\mu \mathrm{m}$; Daiso Co., Japan), MCI gel CHP 20P (75-150 $\mu \mathrm{m}$, Mitsubishi Chemical Industries, Tokyo, Japan) and Sephadex LH-20 (Amersham Pharmacia, Uppsala, Sweden) were used for column chromatography. Semi-preparative HPLC was underwent on an Agilent 1200 liquid chromatograph with an YMC-Pack ODS-A column $(250 \times 10 \mathrm{~mm}$, i.d., $5 \mu \mathrm{m}$, flow rate: $3 \mathrm{~mL} / \mathrm{min})$ and a Daicel Chiralpak (IC, $250 \mathrm{~mm} \times 4.6 \mathrm{~mm}$, i.d., $5 \mu \mathrm{m}$, flow rate: $1 \mathrm{~mL} / \mathrm{min})$.

\subsection{Insect Material}

The specimen of Polyphaga plancyi was purchased from Henan Province, China, in November 2014, and identified by Prof. Da-Rong Yang at Kunming Institute of

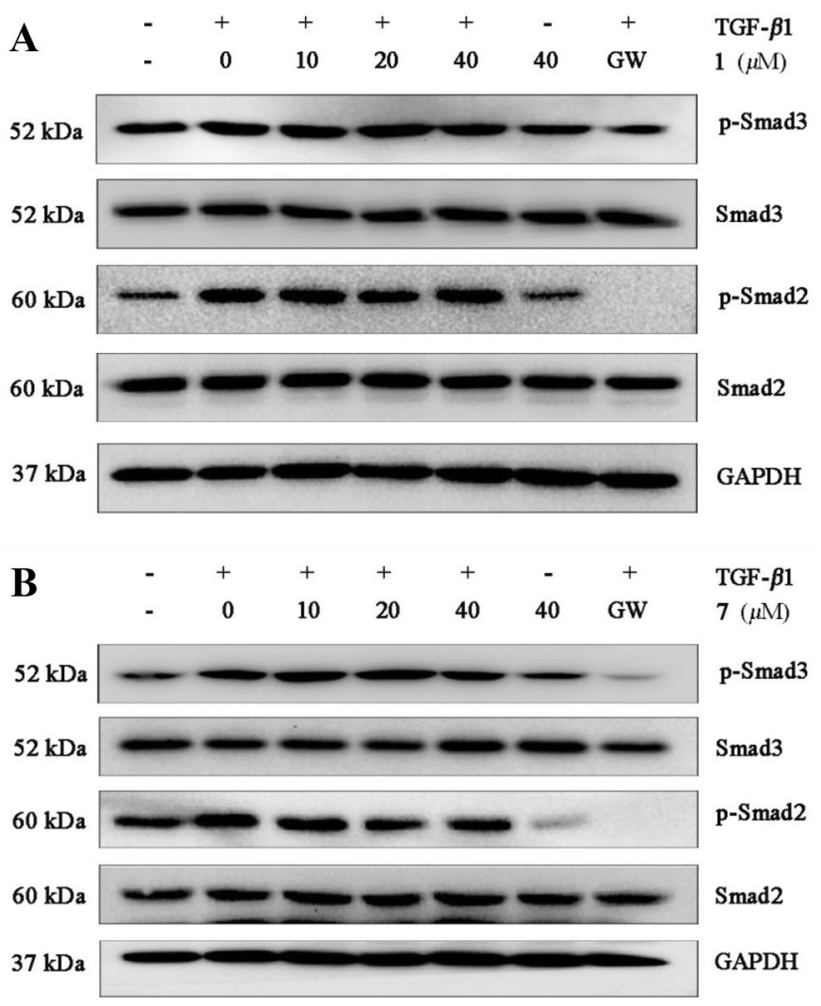

Fig. 9 Western blot analysis showing that 1 and 7 inhibit TGF- $\beta 1-$ induced Smad2/3 phosphorylation in NRK-52e cells. NRK-52e cells were treated with TGF- $\beta 1(10 \mathrm{ng} / \mathrm{mL})$ for $1 \mathrm{~h}$ in the absence or presence of different concentrations of the compounds. Cell lysates were immunoblotted with antibodies against p-Smad3, Smad3, p-Smad2, Smad2, and GAPDH

Table 4 Cytotoxicity against three different human cancer cell lines

\begin{tabular}{llll}
\hline Groups & $\mathrm{IC}_{50}(\mu \mathrm{M})$ & \\
\cline { 2 - 4 } & $\mathrm{K} 562$ & A549 & Huh7 \\
\hline$(+)-3$ & 48.1 & $>70$ & $>70$ \\
$(-)-3$ & 16.6 & 43.1 & 67.7 \\
Taxol & 0.004 & 0.0027 & 0.0099 \\
\hline
\end{tabular}

Table 5 Inhibitory effects of the isolates toward JAK3, ROCK2, DDR1, and EV71

\begin{tabular}{lllll}
\hline Group & \multicolumn{3}{l}{} & \\
\cline { 2 - 5 } & $\mathrm{IC}_{50}(\mu \mathrm{M})$ & & & \\
\hline$(+)-3$ & $\mathrm{NA}^{\mathrm{a}}$ & $\mathrm{NA}^{\mathrm{a}}$ & $\mathrm{NA}^{\mathrm{a}}$ & 23.2 \\
$(-)-3$ & $\mathrm{NA}^{\mathrm{a}}$ & $\mathrm{NA}^{\mathrm{a}}$ & $\mathrm{NA}^{\mathrm{a}}$ & 27.1 \\
$\mathbf{6}$ & 9.17 & 27.1 & $\mathrm{NA}^{\mathrm{a}}$ & $\mathrm{NA}^{\mathrm{a}}$ \\
$(+)-9$ & 9.35 & $\mathrm{NA}^{\mathrm{a}}$ & 23.9 & $\mathrm{NA}^{\mathrm{a}}$ \\
$(-)-9$ & 4.59 & $\mathrm{NA}^{\mathrm{a}}$ & 22.9 & $\mathrm{NA}^{\mathrm{a}}$ \\
Positive drug & Stauro- & Stauro- & Dasatinib & Ribavirin \\
& sporine & sporine & 0.00744 & 0.000384 \\
& 0.00044 & 0.00381 & & \\
\hline
\end{tabular}

${ }^{\mathrm{a}} \mathrm{NA}$ means no activity 
Table 6 Inhibitory effects of the isolates on PT $(n=3)$

\begin{tabular}{llll}
\hline Group & $\begin{array}{l}\text { Detectable level } \\
(\mu \mathrm{M})\end{array}$ & $\begin{array}{l}\text { Plasma level } \\
(\mu \mathrm{M})\end{array}$ & $\begin{array}{l}\text { PT (s) } \\
X \pm \mathrm{SD}\end{array}$ \\
\hline Control & - & - & $16.0 \pm 0.12$ \\
Heparin & 141.09 & 14.11 & $21.4 \pm 0.50^{* * *}$ \\
$(+)-4$ & 200.00 & 20.00 & $16.6 \pm 0.26^{*}$ \\
7 & 200.00 & 20.00 & $16.4 \pm 0.06^{* *}$ \\
\hline
\end{tabular}

$* P<0.05, * * P<0.01, * * * P<0.001$ versus control

Table 7 Inhibitory effects of the isolates on TT $(n=3)$

\begin{tabular}{llll}
\hline Group & $\begin{array}{l}\text { Detectable level } \\
(\mu \mathrm{M})\end{array}$ & $\begin{array}{l}\text { Plasma level } \\
(\mu \mathrm{M})\end{array}$ & $\begin{array}{l}\text { TT (s) } \\
X \pm \mathrm{SD}\end{array}$ \\
\hline Control & - & - & $15.1 \pm 0.15$ \\
Enoxaparin & 35.60 & 3.56 & $20.4 \pm 1.2^{*}$ \\
$(+)-9$ & 200.00 & 20.00 & $16.1 \pm 0.55^{*}$ \\
\hline
\end{tabular}

$* P<0.05$ versus control

Table 8 Inhibitory effects of the isolates on AA induced platelet aggregation in rabbits $(\bar{X} \pm \mathrm{SD}, \mathrm{n}=3)$

\begin{tabular}{|c|c|c|c|c|}
\hline \multicolumn{2}{|l|}{ Group } & \multirow{2}{*}{$\begin{array}{l}\text { Inducer (AA) } \\
\text { Final level }\end{array}$} & \multirow{2}{*}{$\begin{array}{l}\text { Maximum } \\
\text { aggregation } \\
\text { rate }(\%)\end{array}$} & \multirow{2}{*}{$\begin{array}{l}\text { Inhibition rate } \\
(\%)\end{array}$} \\
\hline No. & Final level & & & \\
\hline DMSO & $1 \%$ & - & $1.6 \pm 1.5^{* * *}$ & - \\
\hline Control & $1 \%$ & $0.5 \mathrm{mM}$ & $70.6 \pm 3.4$ & - \\
\hline Aspirin & $27.78 \mu \mathrm{M}$ & & $12.0 \pm 15.1 * * *$ & $82.5 \pm 21.9 * * *$ \\
\hline 5 & $20.00 \mu \mathrm{M}$ & & $65.3 \pm 1.5^{*}$ & $8.2 \pm 4.7 *$ \\
\hline$(+)-9$ & $20.00 \mu \mathrm{M}$ & & $65.0 \pm 2.0^{*}$ & $8.5 \pm 8.8^{*}$ \\
\hline
\end{tabular}

$* P<0.05$, *** $P<0.001$ versus control

Zoology, Chinese Academy of Sciences. A voucher specimen (CHYX-0593) is deposited at the School of Pharmaceutical Sciences, Shenzhen University Health Science Center, People's Republic of China.

\subsection{Extraction and Isolation}

The whole bodies of $P$. plancyi $(50 \mathrm{~kg})$ were extracted under reflux with $70 \% \mathrm{EtOH}(300 \mathrm{~L}, 4 \mathrm{~h}, 3 \mathrm{~h}, 3 \mathrm{~h})$ to give a crude extract $(6.32 \mathrm{~kg})$, which was suspended in water followed by successive partition with petroleum ether and EtOAc to afford an EtOAc soluble extract. This extract (127 g) was divided into six parts (Frs. A-F) by using a MCI gel CHP 20P column eluted with gradient aqueous $\mathrm{MeOH}$ $(10 \%-100 \%)$. Fr. B $(8.1 \mathrm{~g})$ was gel filtrated over Sephadex LH-20 (aqueous $\mathrm{MeOH}, 80 \%$ ) to afford 3 parts (Frs. $\mathrm{B} 1-\mathrm{B} 3)$. Compound $9\left(2.6 \mathrm{mg}, t_{\mathrm{R}}=19.2 \mathrm{~min}\right)$ was obtained from Fr. B3 $(0.40 \mathrm{~g})$ by semi-preparative HPLC (MeCN/ $\mathrm{H}_{2} \mathrm{O}, 13 \%$, flow rate: $\left.3 \mathrm{~mL} / \mathrm{min}\right)$. Fr. $\mathrm{C}(12.0 \mathrm{~g})$ was gel filtrated over Sephadex LH-20 (aqueous $\mathrm{MeOH}, 80 \%$ ) to afford 5 parts (Frs. C1-C5). Fr. C2 $(5.51 \mathrm{~g})$ was submitted to a RP-18 column eluted with gradient aqueous $\mathrm{MeOH}$ (15-50\%) to yield 8 subfractions (Frs. C2.1-C2.8). Fr. C3 (2.45 g) was submitted to a RP-18 column eluted with gradient aqueous $\mathrm{MeOH}(15-50 \%)$ followed by semi-preparative HPLC $\left(\mathrm{MeCN} / \mathrm{H}_{2} \mathrm{O}, 29 \%\right.$, flow rate: $\left.3 \mathrm{~mL} / \mathrm{min}\right)$ to produce $4\left(1.3 \mathrm{mg}, t_{\mathrm{R}}=28.0 \mathrm{~min}\right)$. Fr. C4 (1.71 g) was gel filtrated over Sephadex LH-20 (MeOH) followed by semi-preparative HPLC (MeCN/ $\mathrm{H}_{2} \mathrm{O}, 21 \%$, flow rate: $\left.3 \mathrm{~mL} / \mathrm{min}\right)$ to produce $8\left(2.6 \mathrm{mg}, t_{\mathrm{R}}=27.2 \mathrm{~min}\right)$. Fr. D $(8.7 \mathrm{~g})$ was gel filtrated over Sephadex LH-20 (aqueous $\mathrm{MeOH}, 80 \%$ ) to afford 6 parts (Frs. D1-D6). Further, Fr. D5 (1.23 g) was gel filtrated over Sephadex LH-20 (MeOH) followed by semi-preparative HPLC (MeCN/ $\mathrm{H}_{2} \mathrm{O}, 29 \%$, flow rate: $3 \mathrm{~mL} / \mathrm{min}$ ) to produce $3\left(22.5 \mathrm{mg}, t_{\mathrm{R}}=11.6 \mathrm{~min}\right), \mathbf{1 0}\left(2.5 \mathrm{mg}, t_{\mathrm{R}}=12.3 \mathrm{~min}\right), 7$ $\left(2.1 \mathrm{mg}, t_{\mathrm{R}}=19.2 \mathrm{~min}\right), \mathbf{6}\left(2.8 \mathrm{mg}, t_{\mathrm{R}}=28.4 \mathrm{~min}\right)$, and $\mathbf{5}$ $\left(5.5 \mathrm{mg}, t_{\mathrm{R}}=34.0 \mathrm{~min}\right)$. Fr. D6 (1.01 g) was gel filtrated over Sephadex LH-20 (MeOH) followed by semi-preparative HPLC $\left(\mathrm{MeCN} / \mathrm{H}_{2} \mathrm{O}, 29 \%\right.$, flow rate: $\left.3 \mathrm{~mL} / \mathrm{min}\right)$ to produce $1\left(12.5 \mathrm{mg}, t_{\mathrm{R}}=12.2 \mathrm{~min}\right)$ and $2\left(3.8 \mathrm{mg}, t_{\mathrm{R}}=34.5 \mathrm{~min}\right)$. Notably, compounds $3, \mathbf{4}, \mathbf{8}$, and 9 were isolated as racemates, which were subjected to chiral HPLC to yield (+)-3 $\left(10.1 \mathrm{mg}, t_{\mathrm{R}}=8.3 \mathrm{~min}\right)$ and $(-)-3\left(10.5 \mathrm{mg}, t_{\mathrm{R}}=11.6 \mathrm{~min}\right)$ (n-hexane/ethanol, 85:15, flow rate: $1 \mathrm{~mL} / \mathrm{min}),(+)-4$ $\left(0.7 \mathrm{mg}, t_{\mathrm{R}}=10.4 \mathrm{~min}\right)$ and $(-)-4\left(0.5 \mathrm{mg}, t_{\mathrm{R}}=15.8 \mathrm{~min}\right)$ (n-hexane/ethanol, 80:20, flow rate: $1 \mathrm{~mL} / \mathrm{min}),(+)-8$ $\left(1.4 \mathrm{mg}, t_{\mathrm{R}}=12.5 \mathrm{~min}\right)$ and $(-)-8\left(1.1 \mathrm{mg}, t_{\mathrm{R}}=14.6 \mathrm{~min}\right)$ (n-hexane/ethanol, 90:10, flow rate: $1 \mathrm{~mL} / \mathrm{min}),(+)-9$ $\left(1.2 \mathrm{mg}, t_{\mathrm{R}}=8.9 \mathrm{~min}\right)$ and $(-)-9\left(1.1 \mathrm{mg}, t_{\mathrm{R}}=14.3 \mathrm{~min}\right)$ (n-hexane/ethanol, 77:23, flow rate: $1 \mathrm{~mL} / \mathrm{min}$ ), respectively.

\subsection{Compound Characterization}

Plancyin A (1): Yellowish solid; UV $(\mathrm{MeOH}) \lambda_{\max }(\log$ ع) 288 (3.82), 255 (4.02), 211 (4.45) nm; ESIMS m/z 329 $[\mathrm{M}-\mathrm{H}]^{-}$, HRESIMS $\mathrm{m} / \mathrm{z} 329.1040[\mathrm{M}-\mathrm{H}]^{-}$(calcd for $\left.\mathrm{C}_{18} \mathrm{H}_{17} \mathrm{O}_{6}, 329.1031\right) .{ }^{1} \mathrm{H}$ and ${ }^{13} \mathrm{C}$ NMR data, see Table 1 .

Plancyin B (2): Yellowish solid; UV (MeOH) $\lambda_{\max }(\log$ ع) 291 (3.76), 256 (4.00), 214 (4.54) nm; ESIMS m/z 343 [M-H] $]^{-}$, HRESIMS $\mathrm{m} / \mathrm{z} 343.1193[\mathrm{M}-\mathrm{H}]^{-}$(calcd for $\left.\mathrm{C}_{19} \mathrm{H}_{19} \mathrm{O}_{6}, 343.1187\right) .{ }^{1} \mathrm{H}$ and ${ }^{13} \mathrm{C}$ NMR data, see Table 1.

Plancyin C (3): Yellowish solid; $\left\{[\alpha]_{\mathrm{D}}^{25}+49.5\right.$ (c 0.17, $\mathrm{MeOH}) ; \mathrm{CD}(\mathrm{MeOH}) \Delta \varepsilon_{195}-27.87, \Delta \varepsilon_{208}+15.93$; (+)-3 $\}$; $\left\{[\alpha]_{\mathrm{D}}^{25}-58.0(c 0.16, \mathrm{MeOH}) ; \mathrm{CD}(\mathrm{MeOH}) \Delta \varepsilon_{195}+18.55\right.$, $\left.\Delta \varepsilon_{208}-11.62 ;(-)-3\right\} ; \mathrm{UV}(\mathrm{MeOH}) \lambda_{\max }(\log \varepsilon) 278$ (3.77), 205 (4.80) nm; ESIMS $\mathrm{m} / z 329[\mathrm{M}-\mathrm{H}]^{-}$, HRESIMS $\mathrm{m} / \mathrm{z}$ $329.1036[\mathrm{M}-\mathrm{H}]^{-}\left(\right.$calcd for $\left.\mathrm{C}_{18} \mathrm{H}_{17} \mathrm{O}_{6}, 329.1031\right) .{ }^{1} \mathrm{H}$ and ${ }^{13} \mathrm{C}$ NMR data, see Table 1.

Plancyin D (4): Yellowish solid; $\left\{[\alpha]_{\mathrm{D}}^{25}+86.7(c 0.07\right.$, $\mathrm{MeOH}) ; \mathrm{CD}$ (MeOH) $\Delta \varepsilon_{197}-39.04, \Delta \varepsilon_{209}+15.41$; (+)-4\}; $\left\{[\alpha]_{\mathrm{D}}^{25}-86.5(c 0.05, \mathrm{MeOH}) ; \mathrm{CD}(\mathrm{MeOH}) \Delta \varepsilon_{195}+33.86\right.$, $\Delta \varepsilon_{208}-17.87$; (-)-4\}; UV (MeOH) $\lambda_{\max }(\log \varepsilon) 277$ (3.53), 
205 (4.60) nm; ESIMS $m / z, 343[\mathrm{M}-\mathrm{H}]^{-}$, HRESIMS $\mathrm{m} / \mathrm{z}$ $343.1178[\mathrm{M}-\mathrm{H}]^{-}$(calcd for $\left.\mathrm{C}_{19} \mathrm{H}_{19} \mathrm{O}_{6}, 343.1187\right) .{ }^{1} \mathrm{H}$ and ${ }^{13} \mathrm{C}$ NMR data, see Table 2.

Plancyin E (5): Yellowish solid; UV (MeOH) $\lambda_{\max }(\log$ ع) 277 (3.60), 217 (4.24), 205 (4.60) nm; ESIMS $m / z, 285$ $[\mathrm{M}-\mathrm{H}]^{-}$, HRESIMS $\mathrm{m} / z 285.1133[\mathrm{M}-\mathrm{H}]^{-}$(calcd for $\left.\mathrm{C}_{17} \mathrm{H}_{17} \mathrm{O}_{4}, 285.1132\right) .{ }^{1} \mathrm{H}$ and ${ }^{13} \mathrm{C}$ NMR data, see Table 2.

Plancyin F (6): Yellowish solid; UV (MeOH) $\lambda_{\max }(\log$ ع) 291 (3.72), 208 (4.44) nm; ESIMS $m / z 257[\mathrm{M}-\mathrm{H}]^{-}$, HRESIMS $\mathrm{m} / z, 257.0816[\mathrm{M}-\mathrm{H}]^{-}$(calcd for $\mathrm{C}_{15} \mathrm{H}_{13} \mathrm{O}_{4}$, 257.0819). ${ }^{1} \mathrm{H}$ and ${ }^{13} \mathrm{C}$ NMR data, see Table 2.

Plancyin G (7): Yellowish solid; UV (MeOH) $\lambda_{\max }(\log$ ع) 323 (4.39), 204 (4.39) nm; ESIMS m/z $385[\mathrm{M}-\mathrm{H}]^{-}$, HRESIMS $\mathrm{m} / z 385.0917[\mathrm{M}-\mathrm{H}]^{-}$(calcd for $\mathrm{C}_{20} \mathrm{H}_{17} \mathrm{O}_{8}$, 385.0929). ${ }^{1} \mathrm{H}$ and ${ }^{13} \mathrm{C}$ NMR data, see Table 3.

Plancyin H (8): Yellowish solid; $\left\{[\alpha]_{\mathrm{D}}^{25}+34.9(c 0.11\right.$, $\mathrm{MeOH}) ; \mathrm{CD}(\mathrm{MeOH}) \Delta \varepsilon_{198}+29.58, \Delta \varepsilon_{230}-5.48 ;(+)-8$; $\left\{[\alpha]_{\mathrm{D}}^{25}-29.6\right.$ (c 0.14, $\left.\mathrm{MeOH}\right) ; \mathrm{CD}(\mathrm{MeOH}) \Delta \varepsilon_{198}-37.08$, $\Delta \varepsilon_{237}+2.03$; (-)-8 $\} ; \mathrm{UV}(\mathrm{MeOH}) \lambda_{\max }(\log \varepsilon) 280$ (3.53),

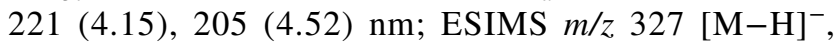
HRESIMS $\mathrm{m} / z 327.0873[\mathrm{M}-\mathrm{H}]^{-}$(calcd for $\mathrm{C}_{18} \mathrm{H}_{15} \mathrm{O}_{6}$, 327.0874). ${ }^{1} \mathrm{H}$ and ${ }^{13} \mathrm{C}$ NMR data, see Table 3.

Periplanol A (9): Yellowish solid; $\left\{[\alpha]_{\mathrm{D}}^{25}+36.1(c\right.$ $0.04, \mathrm{MeOH})$; $\mathrm{CD}(\mathrm{MeOH}) \Delta \varepsilon_{197}-6.41, \Delta \varepsilon_{206}+11.24$, $\left.\Delta \varepsilon_{292}+2.06 ;(+)-9\right\} ;\left\{[\alpha]_{\mathrm{D}}^{25}-12.8(c 0.41, \mathrm{MeOH}) ; \mathrm{CD}\right.$ (MeOH) $\Delta \varepsilon_{196}+7.91, \Delta \varepsilon_{204}-12.17, \Delta \varepsilon_{294}-2.08$; (-)9\}; UV (MeOH) $\lambda_{\max }(\log \varepsilon) 507$ (2.58), 474 (2.59), 290 (3.65), 206 (4.36); ESIMS m/z 303 [M-H] ${ }^{-}$, HRESIMS $m / z$ $303.0863[\mathrm{M}-\mathrm{H}]^{-}$(calcd for $\left.\mathrm{C}_{16} \mathrm{H}_{15} \mathrm{O}_{6}, 303.0874\right) .{ }^{1} \mathrm{H}$ and ${ }^{13} \mathrm{C}$ NMR data, see Table 3.

\subsection{Biological Evaluation for Kidney Fibrosis}

\subsubsection{Cell Culture and Cytotoxicity Assay}

NRK-52e cell lines were maintained in Dulbecco's modified Eagle's medium (DMEM) supplemented with 10\% fetal bovine serum and $100 \mathrm{U} / \mathrm{mL}$ penicillin-streptomycin in $37{ }^{\circ} \mathrm{C}$ with atmosphere of $5 \% \mathrm{CO}_{2}$. The growing cells were seeded at $1 \times 10^{4}$ cells per well in 96-well culture plates for $24 \mathrm{~h}$. Cells were exposed to the compounds with different concentrations $(2.5,5,10,20,40 \mu \mathrm{M})$ for $48 \mathrm{~h}$. The equal volume of DMSO was used as the solvent control. CCK-8 solution $(10 \% \mathrm{v} / \mathrm{v})$ was added and incubated for another $2 \mathrm{~h}$. Light absorbance of the solution was measured at $450 \mathrm{~nm}$ (Epoch 2; BioTek Instruments, Inc.).

\subsubsection{Western Blot Assay}

Protein expression was analyzed by Western blot analysis as described previously [12]. The concentration of all the compounds was $40 \mu \mathrm{M}$ for primary screening and 10 , 20, $40 \mu \mathrm{M}$ for dose-dependent experiments. The primary antibodies as follows: Anti-Fibronectin antibody [IST-9] (\#ab6328; Abcam), COL1A1 Antibody (\#84336; Cell Signaling Technology), $\alpha$-Smooth Muscle Actin (D4K9N) XP® Rabbit mAb (\#19245; Cell Signaling Technology), Smad3 (C67H9) Rabbit mAb (\#9523, Cell Signaling Technology), Phospho-Smad3 (Ser423/425) (C25A9) Rabbit mAb (\#9520, Cell Signaling Technology), Smad2 (D43B4) XP® Rabbit mAb (\#5339, Cell Signaling Technology), Phospho-Smad2 (Ser465/467) (138D4) Rabbit mAb (\#3108, Cell Signaling Technology), GAPDH (D16H11) XP® Rabbit mAb (\#5174, Cell Signaling Technology). Cell pellets were collected and resuspended in RIPA lysis buffer (containing $0.1 \mathrm{mM}$ PMSF). GW: GW788388 (Medchemexpree, HY-10326) [13].

\subsection{Biological Evaluation for Human Cancer Cells (K562, A549, and Huh7), ROCK2, JAK3, and DDR1}

Compounds 1-9 were evaluated for their inhibitory effects against human cancer cells (K562, A549, and Huh7) [14], ROCK2 [15], JAK3 [16], and DDR1 [4] as previously described methods.

\subsection{Biological Evaluation for EV71}

Compounds 1-9 were evaluated for their EV71 inhibitory activities in vitro. VERO cells were plated into 384-well plate at a suitable density and allowed to adhere prior to addition of varying concentrations of drugs. Then the cells were covered with enteroviruses EV71 which was diluted at fresh culture medium. After that, the cells were incubated at $37^{\circ} \mathrm{C}$ for a further $72 \mathrm{~h}$. Then discard the old medium, add fresh medium containing CCK-8, and incubated in $37^{\circ} \mathrm{C}$ for $2 \mathrm{~h}$. The A450 was then measured with an Envision Plate Reader (PerkinElmer).

\subsection{Anticoagulant Assay}

The prothrombin time (PT) and thrombin time (TT) was determined with a coagulometer (TECO MC-4000, Germany). All the reagents were purchased from TECO GmbH (Germany). PT reagent, TT reagent, and normal human plasma was reconstituted in $4 \mathrm{~mL}$ (or $1 \mathrm{~mL}$ for plasma) of distilled water, according to the instructions of the manufacturer. The compounds were dissolved to $2 \mathrm{mM}$ in DMSO at various concentrations. Then use $20 \mathrm{mM}$ Tris- $\mathrm{HCl} \mathrm{pH} 7.4$ (including 5\% Tween 80) diluted to $200 \mu \mathrm{M}$ to be measured. For the PT and TT assays, $5 \mu \mathrm{L}$ samples (or $10 \mu \mathrm{L}$ for TT) were mixed with $45 \mu \mathrm{L}$ (or $90 \mu \mathrm{L}$ for TT) of normal human plasma and incubated for $2 \mathrm{~min}$ at $37{ }^{\circ} \mathrm{C} ; 100 \mu \mathrm{L}$ of PT (or $50 \mu \mathrm{L}$ of TT) reagent was then added and the clotting time was recorded. 


\subsection{Platelet Aggregation Assay}

Turbidometric measurements of platelet aggregation inhibition were performed in a Chronolog Model 700 Aggregometer (Chronolog Corporation, Havertown, PA, USA) according to Born's method [17, 18]. The present study was approved by the Research Ethics Committee of Kunming Institute of Botany, Chinese Academy of Sciences. The blood from the rabbits by ear central arter puncture, were anticoagulated with $3.8 \%$ sodium citrate $(9: 1, \mathrm{v} / \mathrm{v})$. Platelet-rich plasma (PRP) and platelet-poor plasma (PPP) were prepared shortly after blood collection by spinning the sample at $180 \mathrm{~g}$ for $10 \mathrm{~min}$ at $22{ }^{\circ} \mathrm{C}$. The PRP was carefully removed and the remaining blood centrifuged at $2400 \times g$ for $10 \mathrm{~min}$ to obtain PPP. The centrifuge temperature was maintained at $22{ }^{\circ} \mathrm{C}$. Platelet counts were adjusted by the addition of PPP to the PRP to achieve a count of $250 \times 10^{9} / \mathrm{L}$. Platelet aggregation studies were completed within $3 \mathrm{~h}$ of preparation of PRP. Immediately after preparation of PRP, $250 \mu \mathrm{L}$ was transferred into each of the test tubes, with $250 \mu \mathrm{L}$ PPP set as a control. Before addition of inducers, the compounds were incubated with PRP at $37^{\circ} \mathrm{C}$ for $5 \mathrm{~min}$. Final concentration of agonist was: arachidonic acid (AA) $0.5 \mathrm{mM}$ as positive reference. Percentage inhibition by the compounds was calculated according to the formula:

Inhibition rate $(\%)=\frac{(A-B)}{A} \times 100 \%$

where $A$ : maximum change of turbidity in DMSO added, $B$ : maximum change of turbidity in sample added.

\subsubsection{Computational Methods}

Molecular Merck force field (MMFF) and DFT/TDDFT calculations were performed with Spartan'14 software package (Wavefunction Inc., Irvine, CA, USA) and Gaussian 09 program package [19], the conformational search generated low-energy conformers within a $10 \mathrm{kcal} / \mathrm{mol}$ energy was finished by software Conflex 7 . Geometry optimizations of compounds $\mathbf{3}, \mathbf{8}$, and $\mathbf{9}$ were carried out at the DFT/B3LYP/6-311G (d, p) level. The calculated ECD spectra were determined by using Gaussian 09 software employing the TDDFT-B3LYP functional and the 6-311G $(d, p)$ basis sets. ECD calculations further were conducted at the B3LYP SCRF (PCM)/6-311G (d,p) level in MeOH.

Acknowledgements This study was supported by the National Science Fund for Distinguished Young Scholars (81525026) and Shenzhen Government's Plan of Science and Technology (JCYJ20170412110504956).

\section{Compliance with Ethical Standards}

Conflicts of interest The authors declare that they have no conflict of interest.

Open Access This article is licensed under a Creative Commons Attribution 4.0 International License, which permits use, sharing, adaptation, distribution and reproduction in any medium or format, as long as you give appropriate credit to the original author(s) and the source, provide a link to the Creative Commons licence, and indicate if changes were made. The images or other third party material in this article are included in the article's Creative Commons licence, unless indicated otherwise in a credit line to the material. If material is not included in the article's Creative Commons licence and your intended use is not permitted by statutory regulation or exceeds the permitted use, you will need to obtain permission directly from the copyright holder. To view a copy of this licence, visit http://creativecommons.org/licenses/by/4.0/.

\section{References}

1. N.A. Ratcliffe, C.B. Mello, E.S. Garcia, T.M. Butt, P. Azambuja, Insect Biochem. Mol. Biol. 41, 747-769 (2011)

2. A.D. Dossy, Nat. Prod. Rep. 27, 1737-1757 (2010)

3. Chinese Pharmacopeia Committee, Pharmacopeia of the People's Republic of China 1, 15 (2015)

4. H.J. Zhu, Y.M. Yan, Z.C. Tu, J.F. Luo, R. Liang, T.H. Yang, Y.X. Cheng, S.M. Wang, Fitoterapia 114, 163-167 (2016)

5. Y.M. Yan, J. Ai, Y.N. Shi, Z.L. Zuo, B. Hou, J. Luo, Y.X. Cheng, Org. Lett. 16, 532-535 (2014)

6. J. Zhao, H.J. Zhu, X.J. Zhou, T.H. Yang, Y.Y. Wang, J. Su, Y. Li, Y.X. Cheng, J. Nat. Prod. 73, 865-869 (2010)

7. Y.M. Yan, H.Q. Dai, Y.H. Du, B. Schneider, H. Guo, D.P. Li, L.X. Zhang, H. Fu, X.P. Dong, Y.X. Cheng, Bioorg. Med. Chem. Lett. 22, 4179-4181 (2012)

8. Y.N. Shi, Z.C. Tu, X.L. Wang, Y.M. Yan, P. Fang, Z.L. Zuo, B. Hou, T.H. Yang, Y.X. Cheng, Bioorg. Med. Chem. Lett. 24, 5164-5169 (2014)

9. Y.M. Yan, L.J. Li, X.C. Qin, Q. Lu, Z.C. Tu, Y.X. Cheng, Bioorg. Med. Chem. Lett. 25, 2469-2472 (2015)

10. Y.M. Yan, H.J. Zhu, F.J. Zhou, Z.C. Tu, Y.X. Cheng, Tetrahedron 75, 1029-1033 (2019)

11. J. Li, Y.P. Li, F.Y. Qin, Y.M. Yan, H.X. Zhang, Y.X. Cheng, Fitoterapia 142, $104534(2020)$

12. C.W. Luo, S. Zhou, Z.M. Zhou, Y.H. Liu, L. Yang, J.F. Liu, Y.F. Zhang, H.Y. Li, Y.H. Liu, F.F. Hou, L.L. Zhou, J. Am. Soc. Nephrol. 29, 1238-1256 (2018)

13. F. Gellibert, A.C. de Gouville, J. Woolven, N. Mathews, V.L. Nguyen, C. Bertho-Ruault, A. Patikis, E.T. Grygielko, N.J. Laping, S. Huet, J. Med. Chem. 49, 2210-2221 (2006)

14. J.F. Wang, Z. Wang, Z.R. Ju, J.T. Wan, S.R. Liao, X.P. Lin, T.Y. Zhang, X.F. Zhou, H. Chen, Z.C. Tu, Y.H. Liu, Planta Med. 81, 160-166 (2015)

15. J.J. Tang, L. Zhang, L.P. Jiang, L. Di, Y.M. Yan, Z.C. Tu, C.P. Yang, Z.L. Zuo, B. Hou, H.L. Xia, Y.B. Chen, Y.X. Cheng, Tetrahedron 70, 8852-8857 (2014)

16. J.J. Tang, P. Fang, H.L. Xia, Z.C. Tu, B.Y. Hou, Y.M. Yan, L. Di, L. Zhang, Y.X. Cheng, Food Res. Int. 67, 163-168 (2015)

17. G.V.R. Born, Nature 194, 927-929 (1962)

18. G.V.R. Born, M.J. Cross, J. Physiol. 168, 178-195 (1963)

19. M.J. Frisch, G.W. Trucks, H.B. Schlegel, G.E. Scuseria, M.A. Robb, J.R. Cheeseman, G. Scalmani, V. Barone, B. Mennucci, G.A. Petersson, H. Nakatsuji, M. Caricato, X. Li, H.P. Hratchian, A.F. Izmaylov, J. Bloino, G. Zheng, J.L. Sonnenberg, M. Hada, M. Ehara, K. Toyota, R. Fukuda, J. Hasegawa, M. Ishida, T. Nakajima, Y. Honda, 
O. Kitao, H. Nakai, T. Vreven, J.A. Montgomery Jr., J.E. Peralta, F. Ogliaro, M. Bearpark, J.J. Heyd, E. Brothers, K.N. Kudin, V.N. Staroverov, R. Kobayashi, J. Normand, K. Raghavachari, A. Rendell, J.C. Burant, S.S. Iyengar, J. Tomasi, M. Cossi, N. Rega, J.M. Millam, M. Klene, J.E. Knox, J.B. Cross, V. Bakken, C. Adamo, J. Jaramillo, R. Gomperts, R.E. Stratmann, O. Yazyev, A.J. Austin, R. Cammi, C. Pomelli, J.W. Ochterski, R.L. Martin, K. Morokuma, V.G. Zakrzewski, G.A. Voth, P. Salvador, J.J. Dannenberg, S.
Dapprich, A.D. Daniels, O. Farkas, J.B. Foresman, J.V. Ortiz, J. Cioslowski, D.J. Fox, Gaussian 09, Revision A.02 (Gaussian, Inc., Wallingford CT, 2009)

20. Y.M. Yan, H.J. Zhu, B. Xiang, J.J. Qi, Y.X. Cheng, Nat. Prod. Commun. 12, 1769-1772 (2017)

21. W.R. Russell, L. Scobbie, A. Chesson, Bioorg. Med. Chem. 13, 2537-2546 (2005) 